\title{
ENDOSCOPIC HEMOSTASIS IN ULCERATIVE GASTRODUODENAL BLEEDING USING HIGH-FREQUENCY BIOLOGICAL WELDING ELECTROLIGATION
}

DOI: 10.36740/WLek202109123

\author{
Yaroslav P. Feleshtynskyi' ', Sergiy 0. Oparin'², Bogdan V. Sorokin', Margaryta G. Boiarskaia' ${ }^{3}$, Dmytro V. Lutsenko² \\ 'SHUPYK NATIONAL HEALTHCARE UNIVERSITY OF UKRAINE OF THE MINISTRY OF HEALTH OF UKRAINE, KYIV, UKRAINE \\ ${ }^{2}$ MUNICIPAL NON-COMMERCIAL ENTERPRISE OF THE KYIV REGIONAL COUNCIL "KYIV REGIONAL CLINICAL HOSPITAL", KYIV, UKRAINE \\ ${ }^{3}$ KYIV CITY CLINICAL HOSPITAL No.12 (CITY CENTER FOR GASTROINTESTINAL BLEEDING), KYIV, UKRAINE
}

\begin{abstract}
The aim: To increase the efficiency of endoscopic hemostasis in ulcerative gastroduodenal bleeding using high-frequency biological welding electroligation.

Materials and methods: The evaluation of endoscopic hemostasis in 160 patients aged 40 to 85 years with ulcerative gastroduodenal bleeding for the period from 2017 to 2020 was carried out. The patients were divided into two groups: the first (treatment) group involved 80 patients who underwent high-frequency biological welding electroligation, the second (experimental) group consisted of 80 patients who underwent monopolar thermal argon plasma coagulation.

Results: In the first (treatment) group of patients with ulcerative gastroduodenal bleeding, who underwent endoscopic hemostasis using high-frequency biological welding electroligation, primary hemostasis was achieved in 77 cases (96.25\%). In the first group, an early recurrence of bleeding was registered in 3 patients (3.75\%). In the second (experimental) group of patients with ulcerative gastroduodenal bleeding, who underwent endoscopic hemostasis using monopolar thermal argon plasma coagulation, primary hemostasis was achieved in 66 cases (82.5\%). In the second group, a recurrence of bleeding was observed in 14 patients (17.5\%).

Conclusions: The use of high-frequency biological welding electroligation for endoscopic hemostasis in ulcerative gastroduodenal bleeding provides a more reliable permanent hemostasis compared to the use of monopolar thermal argon plasma coagulation (77 (96.5\%) and $66(82.5 \%)$ cases, respectively). The frequency of bleeding recurrence is reduced to $3.5 \%$ and $17.5 \%$, respectively, and the number of surgical interventions for acute bleeding in case of recurrence is decreased to $3(3.5 \%)$ and 7 (8.75\%), respectively.
\end{abstract}

KEY WORDS: ulcerative gastroduodenal bleeding, endoscopic probe, endoscopic hemostasis, high-frequency biological welding electroligation, argon plasma coagulation

Wiad Lek. 2021;74(9 p.l):2159-2162

\section{INTRODUCTION}

At present, ulcerative gastroduodenal bleeding remains a challenging and not fully resolved problem in view of the complexity of tactical approaches, poor treatment outcomes, high overall mortality rate, which is $8-14 \%[1,2]$. Despite the success of endoscopic hemostasis, intensive therapy, the use of modern methods of surgical interventions, postoperative mortality ranges from 10 to $25 \%[1,2]$, and in case of severe ulcerative gastroduodenal bleeding it might be within the range of $15-50 \%[1,3]$, as well as $30-70 \%$ in case of recurrence $[1,3]$.

The analysis of causes of poor treatment outcomes shows that the achievement of the desired results should involve the perfection of methods of endoscopic hemostasis and prevention of early recurrence of bleeding in order to reduce the mortality rate of patients with ulcerative gastroduodenal bleeding. A number of methods of endoscopic hemostasis are in wide use for ulcerative gastroduodenal bleeding control, including chemical (caproferrum, lifusolum), injection (epinephrine: terlipressin 1:20), thermal - monopolar coagulation (diathermocoagulation, hydrodiathermocoagulation, argon plasma coagulation, laser photocoagulation), mechanical (clipping and ligation), combined (injection + argon plasma), etc. Despite the large number of existing methods of endoscopic hemostasis, each has both advantages and disadvantages, which are accompanied by a high recurrence rate of ulcerative gastroduodenal bleeding.

Currently, the most common method of endoscopic hemostasis is monopolar thermal argon plasma coagulation [4]. Despite all its advantages, it still gives cause for concern. A number of experts [4] still believe that argon plasma coagulation does not provide a sufficient coagulation effect on tissues and cannot reliably stop the bleeding from arterial vessels with a diameter of $2 \mathrm{~mm}$ or more deep in the tissue array, and there is a risk of damaging during the procedure of large-diameter vessels that do not bleed, especially in case of ulcerative gastroduodenal bleeding [5].

The literature indicates that the percentage of early recurrence in endoscopic hemostasis using argon plasma coagulation ranges from $15 \%$ to $22 \%$ [5-11]. In this regard, an alternative method of endoscopic hemostasis, namely high-frequency biological welding electroligation has been proposed. 


\section{THE AIM}

To increase the efficiency of endoscopic hemostasis in ulcerative gastroduodenal bleeding using high-frequency biological welding electroligation.

\section{MATERIALS AND METHODS}

The evaluation of endoscopic hemostasis in 160 patients with ulcerative gastroduodenal bleeding for the period from 2017 to 2020 was carried out. The age of patients ranged from 40 to 85 years. The average age was $62.5 \pm 9.1$ years. There were 110 men and 50 women.

The patients were under medical treatment at the clinic of the Department of Proctology of Shupyk National Healthcare University of Ukraine.

Depending on the method of endoscopic hemostasis, the patients were divided into two groups: the first (treatment) group involved 80 patients who underwent high-frequency biological welding electroligation, the second (experimental) group consisted of 80 patients who underwent monopolar thermal argon plasma coagulation. In patients of the first group, endoscopic hemostasis was performed according to the developed technique (Patent of Ukraine for invention UA No.121365) [12].

According to the Forrest classification of bleeding [7], the patients were distributed as follows: the first (treatment) group: FIA - 3 patients (3.75\%); FIB - 14 (17.5\%); FIX - 4 (5\%); FIIA - 28 (35\%); FIIB - 20 (25\%); FIIC - 11 (13.75\%); the second (experimental) group: FIA -7 patients $(8.75 \%)$; FIB - 13 (16.25\%); FIX - 8 (10\%); FIIA - 28 (35\%); FIIB - 19 (23.75\%); FIIC - 5 (6.25\%).

Among 80 patients of the treatment group with ulcerative gastroduodenal bleeding, there were 52 men (65\%) and 28 women (35\%). According to localization, there were $33(40.25 \%)$ cases of gastric ulcers; 44 (56.75\%) cases of duodenal ulcers, including 3 cases of large penetrating ulcers; and $3(3.75 \%)$ cases of postbulbar ulcers. Among 80 patients of the experimental group with ulcerative gastroduodenal bleeding, there were 58 men $(72.5 \%)$ and 22 women (27.5\%). According to localization, there were 31 $(38.75 \%)$ cases of gastric ulcers, including 3 cases of large penetrating ulcers; 46 (57.5\%) cases of duodenal ulcers; and $3(3.75 \%)$ cases of postbulbar ulcers. Thus, the studied groups are comparable in sex composition $(\mathrm{p}=0.306)$ and localization of bleeding $(\mathrm{p}=0.948)$.

The sources of gastrointestinal bleeding in 160 patients were the following: gastric ulcers $(38.3 \%)$, duodenal ulcers (58\%), postbulbar ulcers $(3.70 \%)$. The diameter of bleeding ulcerous defects was from $5 \mathrm{~mm}$ to $40 \mathrm{~mm}(12.2 \mathrm{~mm} \pm 1.2$ on average).

The technique of endoscopic hemostasis of ulcerative gastroduodenal bleeding using high-frequency biological welding electroligation was performed on the EKVZ-300 Patonmed device in automatic welding mode - subtype 5. During videogastroduodenoscopy, a welding high-frequency bipolar probe with an electrode located at the end of the probe is passed through the forceps aperture of the video endoscope directly to the vessel, which bleeds. In this case, the exposure is 15-40 seconds, depending on the vessel diameter. If the vessel diameter is $1-2 \mathrm{~mm}$ of a stomach or duodenum ulcer, a $2.8 \mathrm{~mm}$ probe with a concave electrode is used through a video gastroscope, with a power of $60-70 \mathrm{~W}$ and a temperature of $60{ }^{\circ} \mathrm{C}$ at the end of the electrode. If the vessel diameter is $2-3 \mathrm{~mm}$ of a postbulbar ulcer, a $3.2 \mathrm{~mm}$ probe with a concave electrode is used through a video duodenoscope, with a power of 70-80 W and a temperature of $70-80^{\circ} \mathrm{C}$ at the end of the electrode.

In patients of the second (experimental) group, endoscopic hemostasis was performed using monopolar thermal argon plasma coagulation on the Bowa device. Coagulation occurs without direct contact between the active electrode and the tissue, while the argon flow displaces oxygen from the coagulation zone, which significantly reduces the carbonization (burning) of the tissue. Coagulation was also performed under an angle, as the plasma jet was deflected towards the most conductive (wet) tissues, namely fresh blood, clots.

The evaluation of endoscopic hemostasis was carried out taking into account the effectiveness of hemostasis and the frequency of bleeding recurrence.

\section{RESULTS}

The result of endoscopic hemostasis in ulcerative gastroduodenal bleeding in the treatment group of patients who underwent welding electroligation, as well as in the experimental group of patients who underwent argon plasma coagulation are presented in table I.

In the first (treatment) group of patients with ulcerative gastroduodenal bleeding, who underwent endoscopic hemostasis using high-frequency biological welding electroligation, primary hemostasis was achieved in 77 cases (96.25\%). In this study group, an early recurrence of bleeding after endoscopic hemostasis was registered in 3 patients $(3.75 \%)$ in the first 24 hours. In the second (experimental) group of patients with ulcerative gastroduodenal bleeding, who underwent endoscopic hemostasis using monopolar thermal argon plasma coagulation, primary hemostasis was achieved in 66 cases $(82.5 \%)$. In this study group, a recurrence of bleeding was observed in 14 patients $(17.5 \%)$. This statistical evidence coincides with the literature data from various sources (15-22\%).

In the main group, in $3(3.75 \%)$ patients, endoscopic hemostasis was achieved by a combined method (injection + welding ligation). Combined endoscopic hemostasis was performed in FIA in $3(3.75 \%)$ patients. These patients had large duodenal penetrating ulcers with bleeding vessels larger than $5 \mathrm{~mm}$ in diameter. As a supplementary method for combined endoscopic hemostasis, the injection method was used, in particular adrenaline solution (1:5000). Due to recurrence of bleeding and ineffectiveness of endoscopic hemostasis, 3 patients of the treatment group underwent surgery. They were discharged and referred to outpatient treatment in satisfactory condition.

In the second (experimental) group of patients with ulcerative gastroduodenal bleeding, who underwent 
Table I. Comparative analysis of treatment outcomes.

\begin{tabular}{ccccc}
\hline Parameter & $\begin{array}{c}\text { Treatment group } \\
\mathbf{N = 8 0}\end{array}$ & $\begin{array}{c}\text { Experimental group } \\
\mathbf{N = 8 0}\end{array}$ & OR (95\% Cl) & p \\
\hline Primary hemostasis & $77(96.25 \%)$ & $66(82.5 \%)$ & $5.4(1.4-30.5)$ & $0.005^{*}$ \\
\hline Bleeding recurrence & $3(3.7 \%)$ & $14(17.5 \%)$ & $0.18(0.03-0.7)$ & $0.005^{*}$ \\
\hline
\end{tabular}

OR $(95 \% \mathrm{Cl})$ - relative risk assessment (odds ratio) when comparing the treatment and the experimental groups; $p$ - statistical significance chi-squared test (Fisher's exact test $\left.{ }^{*}-p<0.05\right)$.

endoscopic hemostasis using monopolar thermal argon plasma coagulation, endoscopic hemostasis was performed by a combined method (injection + APC) in $14(17.5 \%)$ patients. On the first day, recurrence was registered in $5(6.25 \%)$ patients, on the second and third days - in 9 $(11.25 \%)$ patients. In these patients with recurrent bleeding, the vessel diameter was more than $2 \mathrm{~mm}$.

During monopolar thermal argon plasma coagulation, in 1 patient with peripapillary duodenum ulcer complicated by intestinal bleeding (Forrest IA, post-hemorrhagic shock of stage I-II), there was a complication in the form of perforation of the anterior-lateral wall of the duodenum. The patient underwent surgery and was discharged and referred to outpatient treatment in satisfactory condition.

In 7 patients with recurrent ulcerative bleeding (on the first and second days) after argon plasma coagulation, welding electroligation was applied resulting in permanent hemostasis. In the other 7 patients with recurrent bleeding and ineffective endoscopic hemostasis, surgical interventions were performed on the third day, which were effective. The patients were discharged and referred to outpatient treatment in satisfactory condition.

The comparison of the results in the study groups indicates a significant increase in the probability of achieving hemostasis in the treatment group by 5.4 times $(\mathrm{OR}=5.4$, $\mathrm{p}=0.005)$; a decrease in the risk of recurrent bleeding in the treatment group by $82 \%(\mathrm{OR}=0.18, \mathrm{p}=0.005)$ and a decrease in the risk of surgical correction of recurrence in the treatment group by $87 \%(\mathrm{OR}=0.13, \mathrm{p}=0.03)$.

All patients of both groups with ulcerative gastroduodenal bleeding who underwent endoscopic hemostasis, were prescribed antiulcer drug therapy using proton pump inhibitors and follow-up videogastroscopy in the postoperative period.

\section{DISCUSSION}

The findings of the use of endoscopic hemostasis in ulcerative gastroduodenal bleeding showed that the best results were obtained in patients of the treatment group using high-frequency biological welding electroligation. In particular, recurrences of ulcerative bleeding were registered only in 3 (3.5\%) patients of the treatment group, while there were $14(17.5 \%)$ cases in the experimental group. Permanent hemostasis was achieved in 77 (96.25\%) patients of the treatment group and $66(82.5 \%)$ patients of the experimental group.

Higher efficiency of endoscopic hemostasis in patients of the treatment group was achieved due to vessel sealing by means of the impedance action of a modulated high-frequency current signal and thanks to an adaptive system for automatic control of the welding process through the contact of a special endoscopic probe with a concave electrode ( $\mathrm{Cu}+$ Mo alloy) [6]. Morphological verification of the efficiency of high-frequency biological welding electroligation of bleeding vessels with a diameter of 1-5 mm was experimentally confirmed. It was found that vessel sealing is followed by total obliteration due to coagulation of the endothelium of the vessel intima, disorganization of the inner elastic membrane, dissection of the outer membrane, covering the adventitia of the vessel [9]. The intestinal mucosa around the sealing zone is not exposed to high temperatures, resulting in a lower percentage of complications [6].

Argon plasma coagulation does not provide a sufficient coagulation effect on tissues and cannot reliably stop the bleeding from arterial vessels deep in the tissue array. Moreover, there is a risk of damaging the walls during argon plasma coagulation [8]. In particular, among patients of the experimental group with ulcerative gastroduodenal bleeding after argon plasma coagulation, a complication such as perforation was registeresd in one (1.25\%) patient who required surgery. In the treatment group of patients where endoscopic hemostasis was performed using high-frequency biological welding electroligation, no perforations were registered.

The method of influencing the bleeding source of high-frequency current during biological welding electroligation is the electrical effect of a modulated signal. And during argon plasma coagulation, there is a thermal effect with the release of a large amount of heat. In addition, the difficulty of energy dosing in the contact mode of argon plasma coagulation provokes the threat of burning the wall of the hollow organ [15], while during welding electroligation, energy dosing is guided by an adaptive system for automatic control of the welding process [6].

Thus, the proposed technique of high-frequency biological welding electroligation has significant advantages over thermal argon plasma coagulation. It provides permanent hemostasis of the vessels from 1 to $5 \mathrm{~mm}$, which in turn can reduce the recurrence rate of bleeding and surgical interventions for acute bleeding.

\section{CONCLUSIONS}

The use of high-frequency biological welding electroligation for endoscopic hemostasis in ulcerative gastroduodenal bleeding provides a more reliable permanent hemo- 
stasis compared to the use of monopolar thermal argon plasma coagulation ( $96.5 \%$ and $82.5 \%$, respectively). The frequency of bleeding recurrence is reduced to $3.5 \%$ and $17.5 \%$, respectively, and the number of surgical interventions for acute bleeding in case of recurrence is decreased to $3(3.5 \%)$ and $7(8.75 \%)$, respectively.

\section{REFERENCES}

1. Fomin P.D., Shepetko E.M. Hirurgichne likuvannya virazkovih gastroduodenalnih krovotech ta korekciya postgemoragichnoï anemiï gemopoetichnimi stovburovimi klitinami. Kyiv: «Feniks». 2011: 7p. (in Ukrainian)

2. Vinokurov M.M., Kapitonova M.A. Taktika likuvannya hvorih z virazkovimi gastroduodenalnimi krovotechami. Hirurgiya. 2008;2: 3336. (in Ukrainian)

3. Lebedev N.V., Klimov A.E., Barhudarova T.V., Malkarov M.A. Taktika likuvannya hvorih z virazkovimi gastroduodenalnimi krovotechami. Visnik hirurgiï. 2007;166: 76-79. (in Ukrainian)

4. Fedorov E.D., Yudin 0.I., Petrov D.U. et al. Effektivnost primeneniya endoskopicheskoj argonoplazmennoj koagulyacii v sravnenii s bipolyarnoj diatermokoagulyaciej pri yazvennyh gastroduodenalnyh krovotecheniyah. RZHGGK. 2008;18: 33. (in Russian)

5. Bereznickij Y.S., Sulima V.P., Yaroshenko K.0. Vibir metodu endoskopichnogo gemostazu pri gostrih shlunkovo-kishkovih krovotechah. 2016:08-111. (in Ukrainian)

6. Paton B.Y., Ivanova 0.N. Tkaninozberigayucha visokochastotna elektrovaryuvalna hirurgiya. Atlas. Kyiv: «Naukova dumka» NAN Ukraïni. 2009.

7. Unifikovanij klinichnij protokol pervinnoï, vtorinnoï (specializovanoï) ta tretinnoï (visokospecializovanoï) medichnoï dopomogi. Shlunkovokishkovi krovotechi: 2016. (in Ukrainian)

8. Shepetko E.M. Hirurgichne likuvannya uskladnenih yukstapapilyarnih virazok. Kyiv. Zhurnal «Raduga». 2012: 12-15. (in Ukrainian)

9. Oparin S.O., FelishtinskijY.P., Dyadih 0.A. Eksperimentalne obgruntuvannya endoskopichnogo likuvannya shlunkovo-kishkovih krovotech za dopomogoyu visokochastotnogo zvaryuvalnogo elektrokoagulyatora. Zhurnal «Morfologiya» 2018: 105 -110. (in Ukrainian)

10. Akin M., Alkan E., Tuna Y., Yalcinkaya T. Comparison of heater probe coagulation and argon plasma coagulation in the management of Mallory-Weiss tears and high-risk ulcer bleeding. 2017;18(1):35-38. doi: 10.1016/j.ajg.2017.01.006.

11. Akin M., Alkan E., Tuna Y., Yalcinkaya T. Comparison of heater probe coagulation and argonplasma coagulation in the management of MalloryWeiss tearsand high-risk ulcer bleeding. Gastroenterol. 2017;8: 52-54.

12. Patent of Ukraine for invention №121365 UA; IPC A61V 18/08 (2006.01) A61N 01/04 (2006.01) A61B 17/22 (2006.01) A61B17/94(2006.01). Method of endoscopic treatment of ulcer gastroduodenal bleeding. - No a2019 02633; app. 08.03.19; published 12.05.20.

13. Patent of Ukraine for utility model №115147 UA; IPC A61B 17/94 (2006.01) A61N1/18 (2006.01) High-frequency bipolar probe for endoscopic minimally invasive surgery. U201608620; app. 05.08.2016; publ. 10.04.2017.
14. Patent of Ukraine for utility model №124885 UA; IPC A61B 18/08 (2006.01) A61B 17/94 (2006.01) A61N 1/18 (2006.01).,Method of treatment of patients with gastrointestinal bleeding. U2017 11167, app. 15.11.2017, publ. 25.04.2018 bull №8.

15. Chumanevich O.A., Bordakov V.N., Gapanovich V.N. et al. "Endoscopic hemostasis in gastroduodenal bleeding." - Minsk, Medical News Magazine. 2016;8(1).

16. Troland D., Stanley A. Endotherapy of Peptic Ulcer Bleeding. Gastrointest Endosc Clin N Am. 2018;28(3):277-289. doi: 10.1016/j.giec.2018.02.002.

17. Eun J. G., JiY. A., Hwoon-Yong J., Young S. P. et al. Effects of argon plasma coagulation on human stomach tissue: An ex vivo study. J Gastroenterol Hepatol. 2017;32(5):1040-1045. doi: 10.1111/jgh.13636.

18. Zippi M., Traversa G., Cocco A. et al. Use of argon plasma coagulation in digestive endoscopy: a concise review. Clin Ter. 2012;163(6):e435-40.

19. Gralnek I. M., Dumonceau J-M., Kuipers E. J. et al. Diagnosis and management of nonvariceal upper gastrointestinal hemorrhage: European Society of Gastrointestinal Endoscopy (ESGE) Guideline. Endoscopy. 2015;47(10):a1-46. doi: 10.1055/s-0034-1393172.

\section{ORCID and contributionship:}

Yaroslav P. Feleshtynskyi: 0000-0003-4376-4265 A,B,C,

Sergiy O. Oparin: 0000-0003-1504-9678 A,B,C,F

Bogdan V. Sorokin: 0000-0003-0511-7550

Margaryta G. Boiarska: 0000-0002-6853-5533 C, D,E

Dmytro V. Lutsenko: 0000-0002-0453-7441 D,E

\section{Conflict of interest:}

The Authors declare no conflict of interest.

\section{CORRESPONDING AUTHOR Oparin 0 . Sergiy}

Shupyk National Medical Academy of Postgraduate

Education of the Ministry of Health of Ukraine

9 Dorohozhytska St., 04112 Kyiv, Ukraine

tel: +38(050) 9524651

e-mail: soparin7@gmail.com

Received: 22.04 .2021

Accepted: 20.08.2021

A - Work concept and design, B - Data collection and analysis, C - Responsibility for statistical analysis, D-Writing the article, $\mathbf{E}$-Critical review, $\mathbf{F}$ - Final approval of the article 